\title{
Spatial distribution of canine Leishmania infantum infection in a municipality with endemic human leishmaniasis in Eastern Bahia, Brazil
}

\author{
Distribuição espacial de infecção canina por Leishmania infantum em um \\ município com leishmaniose humana endêmica no leste da Bahia, Brasil
}

\begin{abstract}
Bruno Milen Varjão'; Flaviane Alves de Pinho',2; Manuela da Silva Solcà3; Ricardo Silvestre ${ }^{4,5}$; Mahyumi Fujimori6; Hiro Goto6; Natasha Milen Varjão'; Roberta Costa Dias³; Stella Maria Barrouin-Melo ${ }^{1,2 *}$ (1)

'Laboratório de Infectologia Veterinária, Hospital-Escola de Medicina Veterinária, Universidade Federal da Bahia - UFBA, Salvador, BA, Brasil ${ }^{2}$ Departamento de Anatomia, Patologia e Clínicas Veterinárias, Escola de Medicina Veterinária e Zootecnia, Universidade Federal da Bahia - UFBA, Salvador, BA, Brasil

${ }_{3}^{3}$ Departamento de Medicina Veterinária Preventiva e Produção Animal, Escola de Medicina Veterinária e Zootecnia, Universidade Federal da Bahia - UFBA, Salvador, BA, Brasil

${ }^{4}$ Instituto de Investigação em Ciências da Vida e Saúde - ICVS, Escola de Medicina, Universidade do Minho, Braga, Portugal ${ }^{5}$ Laboratório Associado ICVS/3B's - Instituto de Investigação em Biomateriais, Biodegradáveis e Biomiméticos, Universidade do Minho, Guimarães, Portugal

${ }^{6}$ Laboratório de Soroepidemiologia e Imunobiologia, Instituto de Medicina Tropical da Faculdade de Medicina, Universidade de São Paulo - USP, São Paulo, SP, Brasil
\end{abstract}

How to cite: Varjão BM, Pinho FA, Solcà MS, Silvestre R, Fujimori M, Goto $H$, et al. Spatial distribution of canine Leishmania infantum infection in a municipality with endemic human leishmaniasis in Eastern Bahia, Brazil. Braz J Vet Parasitol 2021; 30(2): e022620. https://doi.org/10.1590/S1984-29612021034

\begin{abstract}
Efforts to control a zoonotic disease such as visceral leishmaniasis (VL) caused by Leishmania infantum can be successful if they rely on comprehensive data on animal infection. In Bahia state, Brazil, human VL is endemic, yet some areas have no epidemiological data on canine L. infantum infection and canine leishmaniasis (CanL) to date. We aimed to perform an epidemiological study describing the spatial distribution and characterizing canine L. infantum infection in two districts of the municipality of Muritiba, where human cases have occurred. Brazilian official serodiagnostic protocol (ELISA and immunochromatographic tests), PCR and clinical examination were performed in 351 owned dogs. A seroprevalence of 15.7\% (55/351) was found, and L. infantum identified in 88.8\% (32/36) of PCR tested samples. Spatial distribution of positive dogs indicated infection in both urban and rural districts. There was no association between seropositivity and sex or breed, but dogs older than 2 years were 3.8 times more likely to be seropositive $(95 \% \mathrm{Cl} 1.57$ - 9.18) than younger dogs. Among seropositive dogs, $80 \%$ (44/55) had clinical manifestations of CanL: 75\% (33/44) presented dermatopathy, 50\% (22/44) emaciation, and $29.5 \%$ (13/44) ophthalmopathy. This is the first report on canine seroprevalence and natural $L$. infantum infection in Muritiba, Bahia.
\end{abstract}

Keywords: Dog, georeferencing, zoonotic leishmaniosis, One Health, seroepidemiology, zoonosis.

\begin{abstract}
Resumo
O sucesso dos esforços para controlar uma doença zoonótica como a leishmaniose visceral (LV), causada por Leishmania infantum, depende de dados abrangentes sobre a infecção animal. Na Bahia, Brasil, embora a LV humana seja endêmica, diversos municípios, como Muritiba, ainda não dispõem de dados epidemiológicos sobre infecção por L. infantum e leishmaniose canina (LCan). Objetivou-se realizar um estudo epidemiológico para descrever a distribuição espacial e caracterizar a infecção canina por L. infantum em dois distritos de Muritiba, onde notificam-se casos humanos. Foi aplicado o protocolo sorodiagnóstico oficial brasileiro (ELISA e imunocromatografia), PCR e exame clínico em 351 cães domiciliados. Encontrou-se uma soroprevalência de 15,7\% (55/351) e positividade de 88,8\% (32/36) na PCR para L. infantum. A distribuição espacial dos cães positivos
\end{abstract}

Received October 7, 2020. Accepted March 15, 2021.

*Corresponding author: Stella Maria Barrouin-Melo. E-mail: barrouin@ufba.br

This is an Open Access article distributed under the terms of the Creative Commons Attribution License, which permits unrestricted use distribution, and reproduction in any medium, provided the original work is properly cited. 
indicou infecção em ambos os distritos, urbano e rural. Não houve associação entre soropositividade e sexo ou raça, mas cães com idade acima de 2 anos foram 3,8 vezes mais soropositivos (IC 95\% 1,57 - 9,18). Dentre os cães soropositivos, 80\% (44/55) apresentavam manifestações clínicas de LCan: 75\% (33/44) apresentavam dermatopatia; 50\% (22/44) emagrecimento e 29,5\% (13/44) oftalmopatia. Este é o primeiro estudo a determinar a soroprevalência e confirmar a circulação natural de L. infantum e LCan em cães de Muritiba.

Palavras-chave: Cão, Georreferenciamento, leishmaniose zoonótica, Saúde Única, soroepidemiologia, zoonose.

\section{Introduction}

Leishmaniasis is a spectrum of neglected vector-borne diseases caused by different species of protozoan parasites of the genus Leishmania. Leishmaniasis continues to spread worldwide, and as of January 2020, the WHO Global Leishmaniasis program declared 56 countries as endemic for human visceral leishmaniasis (HVL), which is caused by Leishmania infantum in America and Europe and Leishmania donovani in Africa and Asia. More than 90\% of these cases occur in developing countries such as Brazil, Ethiopia, India, Kenya, Somalia, South Sudan and Sudan (Alvar et al., 2012). In Brazil, L. infantum is transmitted mainly by the sand fly Lutzomyia longipalpis, causing a zoonotic infection that affects humans, companion dogs and other domestic and wild mammals (Quinnell \& Courtenay, 2009; Trüeb et al. 2018). In urban areas, the domestic dog has been considered the main reservoir of the parasite and a key element in the epidemiological cycle (Campos et al., 2017). Thus, monitoring canine L. infantum infection and canine leishmaniasis ( $\mathrm{CanL}$ ) cases is crucial to provide reliable data to promote and support One Health programs.

Data on human and canine infections show that the northeastern states of Brazil have the highest incidence and prevalence of zoonotic leishmaniasis when compared to other regions. In 2019, Bahia State ranked third with the highest number of cases of HVL in the Northeast Region, with an estimated incidence of 1 case/100,000 inhabitants (Brasil, 2020; IBGE, 2020a). The number of new cases changes over time and is often underestimated because of underreporting of human cases and the lack of adequate surveillance systems for canine disease.

Studies in different Brazilian regions have performed spatial analyses demonstrating the association between CanL and human VL occurrence (Bevilacqua et al., 2001, Bruhn et al., 2018; Lana et al., 2018; Arruda et al., 2019). Bavia et al. (2005), using remote sensing and geographic information systems classified, between 1990 and 1998, municipalities of the state of Bahia correlating environmental factors to human VL risk. Data on the spatial distribution of canine L. infantum infection are important to delimit the main risk areas for the human disease (Campos et al., 2017; Lins et al., 2018). However, there is still lack of information regarding the geographical distribution of CanL in many municipalities of Bahia, which hampers the comprehension of factors associated with the disease's spreading in the state.

The municipality of Muritiba, in the Recôncavo Baiano region of Bahia, is an example of a district where HVL cases have occurred (Bahia, 2018), but no epidemiological studies covering canine L. infantum infection prevalence have ever been conducted. The absence of data on zoonotic infections hinders efforts to put strategic disease control practices into place in an area where the unstable basic public services of sanitation, health care or education, coupled with a favorable natural environment for the vectors, foster parasite dissemination (Costa et al., 2005).

In this context, the present study aimed to perform a serology-based epidemiological survey using official serological tests as determined by the Health Ministry of Brazil, then a molecular and clinical characterization of CanL in the municipality of Muritiba, Bahia state, and to provide the spatial distribution of canine L. infantum infection cases.

\section{Materials and Methods}

\section{Ethics approval}

The study was conducted in accordance with the ethical principles for animal experimentation adopted by the National Council for Animal Experimentation Control (CONCEA), and approved by the Committee for Ethics in the Use of Animals (CEUA) of the School of Veterinary Medicine and Zootechny of the Federal University of Bahia (EMEVZ-UFBA) under the protocol No. 013/2017. The dogs' owners were informed about the objectives of the study and signed an informed consent form. 


\section{Study location and design}

This cross-sectional study of the canine population took place from March 2018 to July 2019 in the municipality of Muritiba, Bahia State. This area was selected due to its classification as an area of periodic transmission of human VL by L. infantum, whose last notification was recorded in 2018 (Costa, 2019). In addition, there are no official records on the epidemiological situation of canine infection by L. infantum or CanL in the region.

The municipality of Muritiba is located in the Recôncavo Baiano region ( $12^{\circ} 37^{\prime} 35^{\prime \prime}$ south latitude, 38 59'24" west longitude) and is characterized by having an Atlantic forest biome. The municipality is divided into two districts, one urban (Centro) and one rural (São José do Itaporã), and covers a territorial area of $86.311 \mathrm{~km}^{2}$. Muritiba had an estimated population of 29,410 inhabitants in 2020 (IBGE, 2020b). In this municipality, a census performed in 2010 determined a human development index (HDI) of 0.660, indicating low purchasing power and education indices, while the control of water supply and sewage treatment benefited only $14.6 \%$ of the population (IBGE, 2020b).

The sample size in this study was calculated using the following criteria: estimated canine population as $11 \%$ of the human population (Junqueira \& Galera, 2019), an expected prevalence of CanL of 50\%, with a 95\% confidence interval, and a 5\% margin of error. Thus, the calculated sample size was 343 dogs. The inclusion criteria included the following: dogs should be older than 6 months of age regardless of sex and clinical condition, owner's consent, and the area is accessible. Dogs from the two districts (urban and rural) were examined and the sample was accessed by convenience, based on the agreement of the owners to participate in the study and the accessibility of the area. Locales that presented difficult access or that were dangerous due to criminal activity were not visited.

\section{Clinical evaluation and disease staging}

Dogs underwent a clinical examination according to the previously determined criteria in the specialized literature for the clinical presentation of CanL (Solano-Gallego et al., 2011). The assessment of disease severity was based on clinical signs and changes observed at the physical examination and followed the criteria established by Silva et al. (2017) with adaptations. Each clinical sign of disease received a value of 1 (one) if present or zero if absent. If the dog exhibited a total score up to 3 , it was categorized as having mild disease, a total score between 4 and 9 was categorized as moderate disease, and if the dog had total score of 10 and above, it was categorized as having severe disease.

\section{Sampling and serological evaluation}

After the physical examination, samples of peripheral blood were collected from all dogs for serological diagnosis. Serum samples were tested using two serological tests, the Dual Path Platform TR-DPP® immunochromatographic screening test (Biomanguinhos, Fiocruz, BR) and the ELISA-based Canine Visceral Leishmaniasis test (EIE-LVC, Biomanguinhos, Fiocruz, BR), following the manufacturer's recommendations. The diagnostic conclusion was based on the official determination from the Brazilian Ministry of Health (Brasil, 2011), which establishes that a confirmed infection case is when a dog presents positive results in both TR-DPP $₫$ and EIE-LVC tests. Accordingly, a second sample collection was carried out in the dogs that were double-positive in the official serotests, to detect Leishmania infantum DNA thus identifying it as the species that was causing the infection. Approximately $500 \mu \mathrm{L}$ of bone marrow aspirates were collected from the sternum under sedation with acepromazine $(0.05 \mathrm{mg} / \mathrm{kg})$ and local anesthesia with lidocaine (2-5 mg/kg) (Paparcone et al., 2013) for evaluation of L. infantum infection by PCR.

\section{Leishmania infantum DNA detection by PCR}

Total DNA from bone marrow samples was extracted using the commercial Wizard® Genomic DNA Purification Kit (Promega ${ }^{\circledR}$, USA), according to the manufacturer's recommendations. Conventional multiplex PCR was performed for simultaneous detection of the target region of the L. infantum DNA and of the endogenous control region of canine glyceraldehyde-3-phosphate (GAPDH). The primers used for the amplification of the specific region of the endogenous glyceraldehyde-3-phosphate (GAPDH) control were: 5' CCAAAGTTGTCATGGATGACC-3' (F) and 5'-CCTTCATTGACCTCAACTACAT-3' (R) (Birkenheuer et al., 2003). Primers used for the amplification of $L$. infantum DNA were: 5'-CTTTTCTGGTCCCGCGGGTAGG-3' (RV1) and 5'CCACCTGGCCTATTTTACACCA-3' (RV2) (Lachaud et al., 2002). The PCR conditions were: $13.3 \mu \mathrm{L}$ ultrapure water free of RNAse and DNAse; $2.5 \mu \mathrm{L}$ of $10 \mathrm{x}$ buffer (Invitrogen ${ }^{\circledR}$, USA); $1 \mathrm{mM} \mathrm{MgCl2;} 200 \mu \mathrm{M}$ dNTP (Invitrogen ${ }^{\circledR}, \mathrm{USA}$ ); 10 pmol of initiators; $1.2 \mathrm{U}$ of Taq Platinum Polymerase (Invitrogen $\AA_{1}$ USA); and $1 \mu \mathrm{L}$ (80 to $100 \mathrm{ng}$ ) of DNA, in a final reaction volume of $20 \mu \mathrm{L}$. The thermal cycler (Applied 
Biosystems 2720 Thermal Cycler( ${ }^{\circledR}$ ) was adjusted to the following settings: $94^{\circ} \mathrm{C}$ for 2 min; $94^{\circ} \mathrm{C}$ for $30 \mathrm{sec} ; 61^{\circ} \mathrm{C}$ for $30 \mathrm{sec} ; 72^{\circ} \mathrm{C}$ for $30 \mathrm{sec} ; 2^{\circ} \mathrm{C}$ for $5 \mathrm{~min}$ for a total of $35 \mathrm{cycles}$. The amplification products were stained with Syber Gold (Invitrogen ${ }^{\circledR}$, USA) and visualized on a 1.5\% agarose gel, using the gel documentation system Biometra ${ }^{\circledR}$ (BioDocAnalyze, Germany). Products with approximately 450 and 145 base pairs were considered positive for endogenous control (GAPDH) and L. infantum, respectively.

\section{Georeferencing}

During the evaluation of the dogs at their homes, the address was georeferenced in geographic coordinates (SIRGAS2000, UTM 24 South) using Garmin Etrex 10 GPS equipment (Garmin, USA). The coordinates were plotted on the cartographic basis of the municipal network and census sectors using data from the Brazilian Institute of Geography and Statistics (IBGE, 2020b) for the Muritiba municipality. Thematic maps were constructed to demonstrate the spatial distribution of the seropositive dogs for L. infantum infection and their homes. Households with at least one seropositive dog were considered positive. Spatial distribution was performed using the QGIS program (version 3.12).

\section{Statistical analysis}

An analysis of the association between sex, breed, age and domiciliation (to what extent the dogs lived within the household of the owner or also had access to the streets) of the dog versus seropositivity for canine L. infantum infection was performed by calculating the odds ratio and applying the chi-square test $\left(\chi^{2}\right)$ (Martin \& Austin, 1991; CDC, 2019) with a significance level of 0.05 . Additionally, a descriptive analysis of the clinical signs found in dogs was performed to demonstrate their frequencies.

\section{Results and Discussion}

The study was carried out in Muritiba (Figure $1 \mathrm{~A}$ ) because of the demand for veterinary assistance from owners of pet dogs that became sick and eventually had a confirmed diagnosis of L. infantum infection associated with CanL in private veterinary clinics. The seroprevalence of canine L. infantum infection in the municipality of Muritiba, Bahia, Brazil, was determined by an epidemiological survey based on the active search for and examination of 351 dogs using a convenience sampling assessment, according to the inclusion criteria. Among those dogs, 258 $(73.5 \%)$ were housed in the urban area, while $93(26.5 \%)$ lived in a rural area within the municipality. The clinical
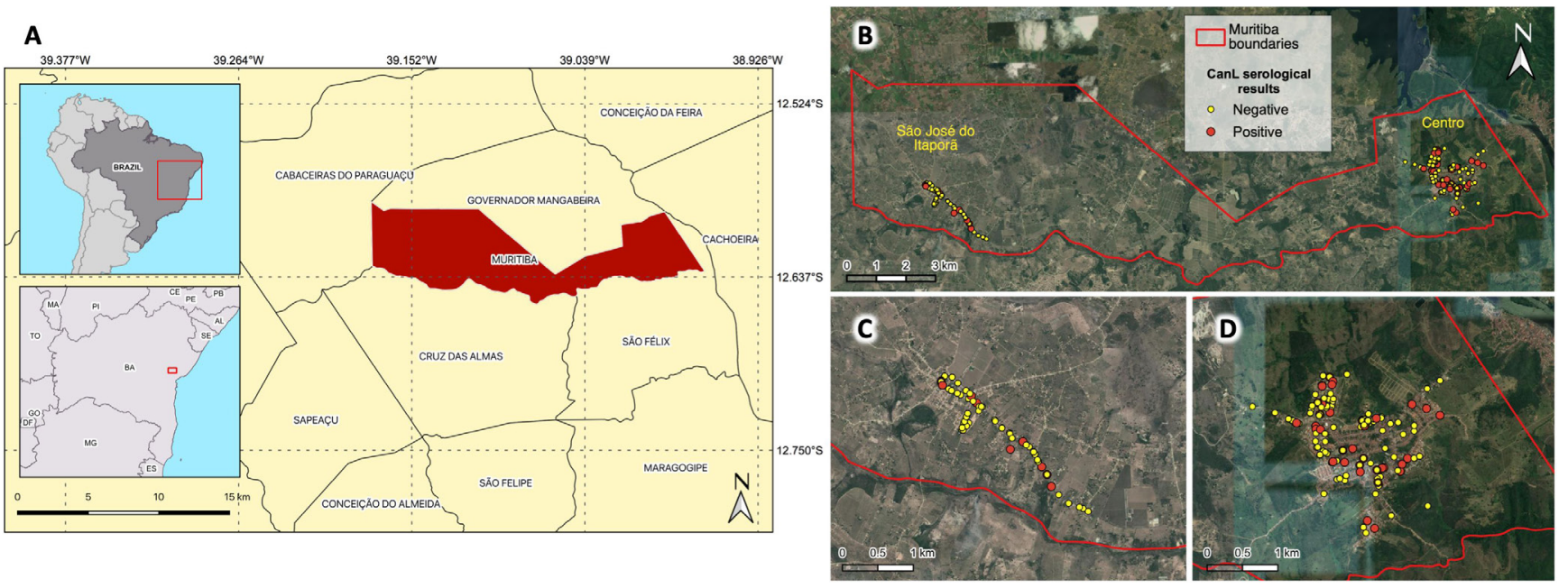

Figure 1. Spatial distribution of seropositive dogs for Leishmania infantum infection in Muritiba, Bahia, Brazil. Seropositivity criterion was the dog being positive for anti-Leishmania antibodies in both, the Dual Path Platform immunochromatographic screening test (TR-DPP $®$ ) and the ELISA-based Canine Leishmaniasis test (EIE-LVC) as determined officially by the Brazilian Ministry of Health (NT 01/2011 - CGDT - CGLAB/DEVIT/SVS/MS) (Brasil, 2011). Geographical location of the municipality of Muritiba, in the Recôncavo Baiano, Bahia State, Brazil (A) Distribution of cases of canine L. infantum seropositivity within the municipality of Muritiba (B), Brazil, in the localities of São José do Itaporã (C) and Centro (D). Yellow dots indicate seronegative dogs, red dots indicate seropositive dogs. Source IBGE (2020b), Datum: SIRGAS2000 (IBGE, 2005), Geographic coordinates. 
characteristics of the evaluated canine population are detailed in Table 1, where the majority was characterized by males (50.6\%), mongrels (63.5\%), adults or old (71.5\%) and strictly domiciled (57.8\%) dogs.

Canine sera were initially screened using the TR-DPP® immunochromatographic test, which detected 98 out of 351 (27.9\%) dogs as positive. Among these seropositive dogs in the TR-DPP® test, 56.1\% (55/98) were confirmed as positive by the EIE-LVC ${ }^{\circ}$ test. These results represent a prevalence of positive cases of $15.7 \%(55 / 351)$, in accordance with the Brazilian Ministry of Health criteria, which defines a dog that tests positive for both, the TRDPP $\circledast$ immunochromatographic test and the EIE-LVC $®$ test, as a confirmed case of canine L. infantum infection (Brasil, 2011). Among the 55 dogs confirmed as seropositive cases, 45 (17.4\%) dogs were housed in urban area and 10 (10.7\%) in rural area. No statistically significant association was found in the analysis between areas (Table 1).

Table 1. Association between seropositivity in both tests for canine leishmaniasis, the TR-DPP $®$ immunochromatographic test and the ELISA-based EIE-LVC® test, and the characteristics of the studied population of 351 dogs from the municipality of Muritiba, Bahia state, Brazil, evaluated from March 2018 to July 2019.

\begin{tabular}{|c|c|c|c|c|c|}
\hline \multirow{2}{*}{ Parameters } & \multirow{2}{*}{$\begin{array}{l}\text { Total number of } \\
\text { dogs (\%) }\end{array}$} & \multicolumn{2}{|c|}{$\begin{array}{c}\text { Serology Result } \\
\text { number of dogs (\%) }\end{array}$} & \multirow{2}{*}{$\mathrm{OR}^{\mathrm{a}}\left(\mathrm{CI}^{\mathrm{b}} \mathbf{9 5 \%}\right)$} & \multirow{2}{*}{ p-value* } \\
\hline & & Positive & Negative & & \\
\hline \multicolumn{6}{|l|}{ Sex } \\
\hline Female & $174(49.6)$ & $28(50.9)$ & $146(49.3)$ & $0.9386(0.52-1.67)$ & 0.83 \\
\hline Male & $177(50.5)$ & $27(49.1)$ & $150(50.7)$ & & \\
\hline \multicolumn{6}{|l|}{ Breed } \\
\hline Mongrel & $223(63.5)$ & $38(69.1)$ & $185(62.5)$ & $1.34(0.72-2.49)$ & 0.35 \\
\hline Pure breed & $128(36.5)$ & 17 (30.9) & $111(37.5)$ & & \\
\hline \multicolumn{6}{|l|}{ Age } \\
\hline Adult (> 2 years) & $251(71.5)$ & $49(89.1)$ & $202(68.2)$ & $3.80(1.57-9.18)$ & 0.0017 \\
\hline Young (<2 years) & $100(28.5)$ & $6(10.9)$ & $94(31.8)$ & & \\
\hline \multicolumn{6}{|l|}{ Domiciliation } \\
\hline Semi-domiciled & $148(42.2)$ & $26(47.3)$ & $122(41.2)$ & $1.28(0.72-2.28)$ & 0.4043 \\
\hline Domiciled & $203(57.8)$ & $29(52.7)$ & $174(58.8)$ & & \\
\hline \multicolumn{6}{|l|}{ Muritiba's district } \\
\hline Centro (urban) & $258(73.5)$ & 45 (17.4) & $213(82.6)$ & $1.75(0.84-3.64)$ & 0.1282 \\
\hline São José do Itaporã & $93(26.5)$ & $10(10.7)$ & $83(89.3)$ & & \\
\hline
\end{tabular}

*Chi-square test. ${ }^{\mathrm{a}} \mathrm{OR}=$ Odds ratio; ${ }^{\mathrm{b}} \mathrm{Cl}=$ Confidence interval.

Among the 55 dogs that were positive in the serological methods, 36 (65.5\%) had bone marrow samples tested by PCR, which confirmed that $L$. infantum was the species responsible for the infection. The remaining 19 dogs were not tested because it was not possible to collect bone marrow samples. Some seropositive dogs died between the first and second sample collection, or the owners decided not to consent to the second procedure. The results of the PCR assays were positive for the detection of L. infantum DNA in 88.8\% (32/36) of the samples.

The spatial distribution of the seropositive dogs showed the presence of canine $L$. infantum infection and CanL in both urban and rural districts (Figure 1B). Although we were able to examine an adequate number of dogs in relation to the local demography, the distribution of the canine population sample was taken by convenience. Furthermore, an attempt to perform cluster Kernel's analysis to identify hot spots for L. infantum infection would not be precise enough, due to the lack of official information on the canine population density in the two districts. However, this shows the need for more studies in the area. Spatial distribution studies provide a diagnosis that can be used to indicate the risks to which the population is exposed, monitor the spread of the disease, provide subsidies for causal explanations, define intervention priorities and assess the impact of interventions (Hino et al., 2006). 
In 2006, a study conducted in another municipality, also located in the Recôncavo Baiano region, showed a lower prevalence of CanL, which was calculated as $10 \%$ of the tested populations (Souza et al. 2006). It is possible that the frequency of infected dogs in the region has increased with time considering the time lapse between the two studies. Interestingly, we did not find any significant difference in the frequency of seropositive dogs between the two areas $\left(X^{2}=2.315 ; p=0.1282\right)$, with $17.4 \%(45 / 258)$ and $10.8 \%(10 / 93)$ positive cases in urban and rural areas of Muritiba, respectively. This finding reinforces the idea that the urbanization of zoonotic leishmaniasis has taken place even in small urban areas. This process can be attributed to socioeconomic and environmental aspects of the study area, which is characterized by having a population that is low income and has less education, while living in areas that are poorly serviced by public services concerning sanitation and infrastructure. Such factors favor the accumulation of waste and the availability of organic material, providing plenty of conditions for vector adaptation, as previously described (Costa et al., 2005).

Among the 55 dogs confirmed as seropositive cases, 28 (50.9\%) were female, 38 (69.1\%) were mongrel, and 29 $(52.7 \%)$ were strictly domiciled (Table 1$)$. No statistically significant association was found in the analysis of these variables. Currently, there is no consensus about which phenotypical characteristics are associated with a higher susceptibility to develop infection by L. infantum and CanL manifestations. However, the dog's genetic immunological susceptibility to Leishmania, environmental factors and socioeconomic condition of the human population are the major risk factors associated with a higher canine L. infantum prevalence (Belo et al., 2013). Our studied population reflects the general characteristics of dogs in the more deprived Brazilian environments, having more mongrels than bred dogs, with half of them having free access to the streets. Indeed, dogs that were strictly domiciled were not more protected than dogs that roamed free, which is expected for a flying vector-borne disease.

In the present study, dogs older than 2 years were 3.8 times more likely to be seropositive for L. infantum infection ( $95 \% \mathrm{Cl} 1.57$ - 9.18) than younger dogs (Table 1). As described previously, younger dogs (<1 year old) and older dogs (> 8 years old) are more prone to Leishmania spp. infection with fatal disease progression, probably due to their immature or less functional immune response, which might render them more susceptible to higher parasite loads and/or to comorbidities (Solano-Gallego et al., 2011). In this regard, we suppose that the more susceptible dogs might have died more often and thus were less represented in the canine population of the studied endemic area, while adult dogs survived long enough to develop an insidious chronic disease and tested positive in a survey.

Most of the dogs assessed in this study presented a poor clinical condition, regardless of canine L. infantum seropositivity, with high frequencies of nonspecific clinical signs such as weight loss, dehydration and skin lesions. Only 11 out of 55 (20\%) of the double-seropositive dogs had no clinical signs of disease, while the other $44(80 \%)$ had clinical manifestations of CanL. The poor clinical condition found in the dogs can be attributed to the lower indices of human development of the owners, hampering the supply of adequate nutrition to their dogs, as well as veterinary care that results in the lack of preventive care and, ultimately, the diagnosis of a life-threatening disease such as CanL. This finding should be seen as an important indication that the area requires public attention considering the principles of One Health.

Regarding the frequency of cutaneous manifestations found in the seropositive population, $75 \%$ (33/44) of the dogs had skin ulcers, alopecia and onychogryphosis. Among the other clinical signs of CanL, the most frequently observed were weight loss, present in 50\% (22/44) of the dogs, lymph node enlargement in 43.2\% (19/44), spleen enlargement in 34.1\% (15/44), ocular alterations in 29.5\% (13/44) and pale mucous membranes in 25\% (11/44). Among the positive dogs with clinical signs, 45.4\% (20/44) had CanL classified as mild, 43.2\% (19/44) as moderate and $11.4 \%$ as severe (5/44) (Figure 2). Other diseases, such as ehrlichiosis, anaplasmosis and babesiosis, can coexist in the same endemic areas as CanL, causing coinfections that lead to an aggravation of the dogs' clinical condition (Krawczak et al., 2015).

In the context of One Health, epidemiological studies should monitor canine Leishmania infection prevalence by determining the dog's clinical status to estimate the risk of transmission of the pathogen between mammalian hosts and vectors. Multiple authors have demonstrated a significantly positive correlation between CanL clinical staging, parasite load and infectivity to the vector. In line with this finding, Courtenay et al. (2002) had already demonstrated that sick dogs transmitted the L. infantum parasite to the vector three times more than dogs with subclinical infections.

Concerning the PCR positivity for L. infantum DNA, it is interesting to note that among the 36 double-seropositive dogs that had their bone marrow tested by PCR, the only four PCR-negative dogs also had no clinical alterations, although they were seropositive in both serological tests. There is a possibility that some seropositive results can occur because of antibody cross-reaction with hemoparasite infections that affect dogs, as has already been 

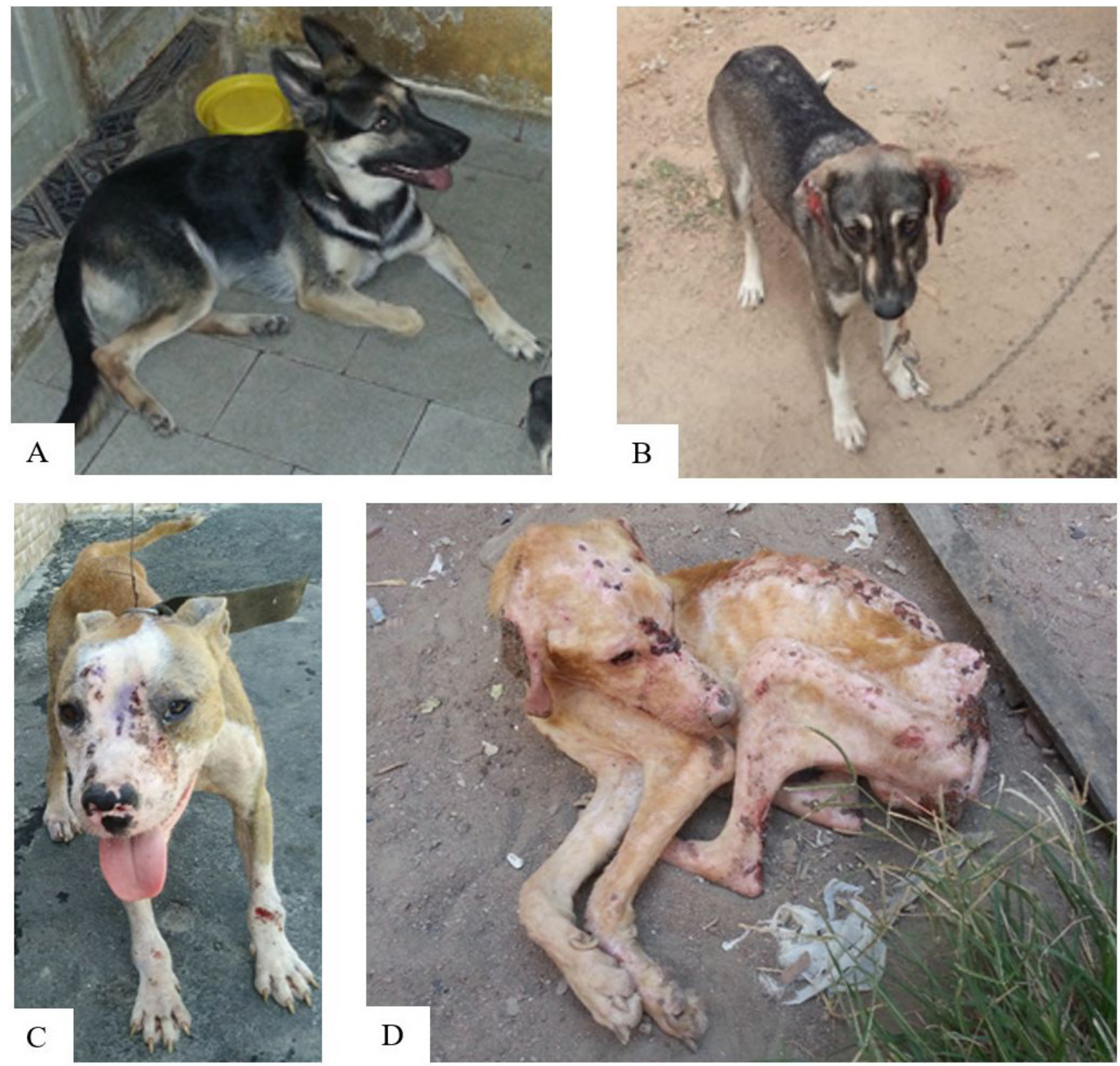

Figure 2. Clinical manifestations in dogs naturally infected with Leishmania infantum in Muritiba, Bahia, Brazil. Dogs were positive in both serological tests, the Dual Path Platform immunochromatographic screening test (TR-DPP®) and the ELISA-based Canine Leishmaniasis test (EIE-LVC) as determined officially by the Brazilian Ministry of Health (NT 01/2011 - CGDT - CGLAB/DEVIT/ SVS/MS), and in the molecular test PCR for L. infantum. (A) Infected dog, apparently healthy; (B) Dog with mild CanL showing ulcers on the tips of the ears; (C) Dog with moderate CanL showing emaciation and dermatological lesions on the face and limbs characterized by desquamation and ulceration; (D) Dog with severe CanL showing cachexia, pale membrane mucous, and generalized dermatological lesions characterized by alopecia, desquamation and ulceration.

reported (Alves et al., 2012). Another possibility is that the seropositivity of these dogs might have indeed resulted from exposure to the parasite, but they possibly had a lower parasite load in the bone marrow than that of the PCRpositive dogs at the time of sample collection. As this was a cross-sectional study, we could not determine the stage of the infection. However, in veterinary clinical settings, the data found in the present study strongly recommends a confirmatory test using a more specific diagnostic method, such as PCR, to support a seropositive result in dogs.

The total number of households assessed in Muritiba was 226, with 161 households in the urban district and 65 in the rural district. In the urban district, there was at least one seropositive dog for Leishmania infection in $22.4 \%$ $(36 / 161)$ of the households, while in the rural district, $13.8 \%$ (9/65) of the households had at least one seropositive dog. The occurrence of canine seropositivity in the two districts of the studied municipality might be related to the anthropic occupation in the Recôncavo Baiano region, leading to the deforestation of the Atlantic forest and ecological imbalance. In addition to the environmental impact, the two districts lack adequate sanitation conditions. 
These factors contribute to Leishmania vector adaptation in households, which makes humans and dogs more susceptible to sandfly bites and Leishmania infection.

The most recent official notification of a case of human VL caused by L. infantum in Muritiba occurred in 2018. According to the criteria of the Brazilian Ministry of Health, Muritiba would be close to being considered a municipality free of VL transmission. However, no human epidemiological survey has been reported for the area since then. On the other hand, here we report for the first time the occurrence of canine infection by L. infantum in the municipality, showing the circulation of the parasite among canine hosts. Parasite transmission to humans can occur at any time, especially if control strategies for human VL are not implemented.

The present study provides evidence of the natural circulation of $L$. infantum in Muritiba as an etiological agent of spontaneous canine disease that confirms the characteristics described for CanL in other endemic areas of Brazil (Nery et al., 2017) and in Europe (Solano-Gallego et al., 2011). Studies with more robust experimental designs are needed to determine the endemicity of canine L. infantum infection and CanL in the whole area of Recôncavo Bahiano, including Muritiba and other municipalities. Likewise, entomological surveillance is also important to identify the vector species involved in the epidemiological cycle of $L$. infantum in the region.

\section{Acknowledgements}

This work was financed by the Federal University of Bahia (PaexDoc Tessituras-UFBA/2020 grant $n^{\circ} 15507$ to F.A.P.; PaexDoc-UFBA/2019: grant $n^{\circ} 11792$ to F.A.P. and grant $n^{\circ} 11436$ to S.M.B-M.), by the Brazilian agencies the Bahia Foundation for Research Support - FAPESB (Grant n' PRONEM 498/2011-PNE 0002/2011 to S.M.B-M.; and MSc scholarship n ${ }^{\circ}$ BOL0434/2018 to B.M.V.), the National Council for Scientific and Technological Development - CNPq (PQ fellowship n 307813/2018-5 to S.M.B-M., and n 302940/2019-7 to H.G.) and the Coordenação de Aperfeiçoamento de Pessoal de Nível Superior - CAPES (Finance Code 001: PV scholarship n 23066.033859/201873 to R.S.). This work also received a partial support by grants from the Northern Portugal Regional Operational Programme (NORTE 2020), under the Portugal 2020 Partnership Agreement, through the European Regional Development Fund (FEDER) (NORTE-01-0145-FEDER-000013), funded by FEDER funds through COMPETE2020 Programa Operacional Competitividade e Internacionalização (POCl) and the Fundação para a Ciência e Tecnologia (FCT) (contract IF/00021/2014 to R.

\section{References}

Alvar J, Vélez ID, Bern C, Herrero M, Desjeux P, Cano J, et al. Leishmaniasis worldwide and global estimates of its incidence. PLoS One 2012; 7(5): e35671. http://dx.doi.org/10.1371/journal.pone.0035671. PMid:22693548.

Alves AS, Mouta-Confort E, Figueiredo FB, Oliveira RVC, Schubach AO, Madeira MF. Evaluation of serological cross-reactivity between canine visceral leishmaniasis and natural infection by Trypanosoma caninum. Res Vet Sci 2012; 93(3): 1329-1333. http:// dx.doi.org/10.1016/j.rvsc.2012.07.006. PMid:22840335.

Arruda RMF, Cardoso DT, Teixeira-Neto RG, Barbosa DS, Ferraz RK, Morais MHF, et al. Space-time analysis of the incidence of human visceral leishmaniasis (VL) and prevalence of canine VL in a municipality of southeastern Brazil: identification of priority areas for surveillance and control. Acta Trop 2019; 197: 105052. http://dx.doi.org/10.1016/j.actatropica.2019.105052. PMid:31233726.

Bahia. Governo do Estado. Secretaria de Saúde da Bahia - SESAB. Situação Epidemiológica Atual. Informe Epidemiológico de Leishmaniose Visceral (LV) - Bahia [online]. 2018;1:1-4. [cited 2020 Sep 17]. Available from: http://www.saude.ba.gov.br/wp-content/ uploads/2017/11/2018-Boletim-de-Leishmaniose-Vivsceral-n.-01.pdf

Bavia ME, Carneiro DDMT, Gurgel HC, Madureira-Filho C, Barbosa MGR. Remote sensing and geographic information systems and risk of american visceral leishmaniasis in Bahia, Brazil. Parassitologia 2005; 47(1): 165-169. PMid:16044686.

Belo VS, Werneck GL, Barbosa DS, Simões TC, Nascimento BWL, da Silva ES, et al. Factors associated with visceral leishmaniasis in the Americas: a systematic review and meta-analysis. PLoS Neg/ Trop Dis 2013; 7(5): e2182. http://dx.doi.org/10.1371/journal. pntd.0002182. PMid:23638203.

Bevilacqua PD, Paixão HH, Modena CM, Castro MCPS. Urbanização da leishmaniose visceral em Belo Horizonte. Arq Bras Med Vet Zootec 2001; 53(1): 1-8. http://dx.doi.org/10.1590/S0102-09352001000100001.

Birkenheuer AJ, Levy MG, Breitschwerdt EB. Development and evaluation of a seminested PCR for detection and differentiation of Babesia gibsoni (Asian genotype) and B. canis DNA in canine blood samples. J Clin Microbiol 2003; 41(9): 4172-4177. http:// dx.doi.org/10.1128/JCM.41.9.4172-4177.2003. PMid:12958243. 
Brasil. Ministério da Saúde. Nota técnica conjunta Nº 01/2011 - CGDT - CGLAB/DEVIT/SVS/MS [online]. Brasília: Ministério da Saúde; 2011 [cited 2020 Sep 17]. Available from: http://www.sgc.goias.gov.br/upload/arquivos/2012-05/nota-tecnica-no.-1-2011_cglab_ cgdt1_Ivc.pdf

Brasil. Ministério da Saúde. Casos confirmados de leishmaniose visceral, Brasil, Grandes Regiões e Unidades Federadas. 1990 a 2019 [online]. Brasília: Ministério da Saúde; 2020 [cited 2020 Sep 17]. Available from: https://portalarquivos.saude.gov.br/images/ pdf/2020/August/25/LV-Casos.pdf

Bruhn FRP, Morais MHF, Cardoso DL, Bruhn NCP, Ferreira F, Rocha CMBM. Spatial and temporal relationships between human and canine visceral leishmaniases in Belo Horizonte, Minas Gerais, 2006-2013. Parasit Vectors 2018; 11(1): 372. http://dx.doi. org/10.1186/s13071-018-2877-6. PMid:29954428.

Campos R, Santos M, Tunon G, Cunha L, Magalhães L, Moraes J, et al. Epidemiological aspects and spatial distribution of human and canine visceral leishmaniasis in an endemic area in northeastern Brazil. Geospat Health 2017; 12(1): 503. http://dx.doi. org/10.4081/gh.2017.503. PMid:28555473.

Centers for Disease Control and Prevention - CDC. Epi Info [online]. Atlanta: CDC; 2019 [cited 2020 Sep 17]. Available from: https://www.cdc.gov/epiinfo/

Costa CHN, Werneck GL, Rodrigues L Jr, Santos MV, Araújo IB, Moura LS, et al. Household structure and urban services: neglected targets in the control of visceral leishmaniasis. Ann Trop Med Parasitol 2005; 99(3): 229-236. http://dx.doi. org/10.1179/136485905X28018. PMid:15829132.

Costa LB. Epidemiologia da leishmaniose visceral na Bahia [Tese]. Salvador: Universidade Federal da Bahia; 2019.

Courtenay O, Quinnell RJ, Garcez LM, Shaw JJ, Dye C. Infectiousness in a cohort of brazilian dogs: why culling fails to control visceral leishmaniasis in areas of high transmission. J Infect Dis 2002; 186(9): 1314-1320. http://dx.doi.org/10.1086/344312. PMid:12402201.

Hino P, Villa TC, Sassaki CM, Nogueira JA, dos Santos CB. Geoprocessing in health area. Rev Lat Am Enfermagem 2006; 14(6): 939943. http://dx.doi.org/10.1590/S0104-11692006000600016. PMid:17294029.

Instituto Brasileiro de Geografia e Estatistica - IBGE. Sistema de Referência Geocêntrico para as Américas - SIRGAS2000. Resolução do Presidente 1/2005. Altera a caracterização do Sistema Geodésico Brasileiro [online]. Rio de Janeiro: IBGE; 2005 [cited 2021 Mar 26]. Available from: https://geoftp.ibge.gov.br/metodos_e_outros_documentos_de_referencia/normas/rpr_01_25fev2005.pdf

Instituto Brasileiro de Geografia e Estatística - IBGE. Bahia [online]. Rio de Janeiro: IBGE; 2020a [cited 2021 Mar 26]. Available from: https://cidades.ibge.gov.br/brasil/ba/panorama

Instituto Brasileiro de Geografia e Estatística - IBGE. Muritiba [online]. Rio de Janeiro: IBGE; 2020b [cited 2020 Sep 17]. Available from: https://cidades.ibge.gov.br/brasil/ba/muritiba/panorama

Junqueira ANN, Galera PD. Characteristics of the population of dogs and cats in Brazil. Acta Vet Bras 2019; 13(2): 77-86. http:// dx.doi.org/10.21708/avb.2019.13.2.8028.

Krawczak FS, Reis IA, Silveira JA, Avelar DM, Marcelino AP, Werneck GL, et al. Leishmania, Babesia and Ehrlichia in urban pet dogs: co-infection or cross-reaction in serological methods? Rev Soc Bras Med Trop 2015; 48(1): 64-68. http://dx.doi.org/10.1590/00378682-0291-2014. PMid:25860466.

Lachaud L, Chabbert E, Dubessay P, Dereure J, Lamothe J, Dedet JP, et al. Value of two PCR methods for the diagnosis of canine visceral leishmaniasis and the detection of asymptomatic carriers. Parasitology 2002; 125(Pt 3): 197-207. http://dx.doi.org/10.1017/ S0031182002002081. PMid:12358417.

Lana RS, Michalsky ÉM, Lopes LO, Lara-Silva FO, Nascimento JL, Pinheiro LC, et al. Ecoepidemiological aspects of visceral leishmaniasis in an endemic area in the Steel Valley in Brazil: an ecological approach with spatial analysis. PLoS One 2018; 13(10): e0206452. http://dx.doi.org/10.1371/journal.pone.0206452. PMid:30376577.

Lins TNB, Souza IB, Barros GMMR, Santos CVB, Silva RP, Alves LC, et al. Seroprevalence and spatial distribution of canine leishmaniasis in an endemic region in Brazil: how has the situation changed after 10 years? Rev Soc Bras Med Trop 2018; 51(5): 680-682. http://dx.doi.org/10.1590/0037-8682-0087-2018. PMid:30304278.

Martin D, Austin H. An efficient program for computing conditional maximum likelihood estimates and exact confidence limits for a common odds ratio. Epidemiology 1991; 2(5): 359-362. http://dx.doi.org/10.1097/00001648-199109000-00008. PMid:1742385.

Nery G, Becerra DRD, Borja LS, Magalhães-Junior JT, Souza BMPS, Franke CR, et al. Avaliação da infectividade parasitária a Lutzomyia longipalpis por xenodiagnóstico em cães tratados para leishmaniose visceral naturalmente adquirida. Pesq Vet Bras 2017; 37(7): 701-707. http://dx.doi.org/10.1590/s0100-736x2017000700009.

Paparcone R, Fiorentino E, Cappiello S, Gizzarelli M, Gradoni L, Oliva G, et al. Sternal aspiration of bone marrow in dogs: a practical approach for canine leishmaniasis diagnosis and monitoring.J Vet Med 2013; 2013: 217314. http://dx.doi.org/10.1155/2013/217314. PMid:26464903. 
Quinnell RJ, Courtenay O. Transmission, reservoir hosts and control of zoonotic visceral leishmaniasis. Parasitology 2009; 136(14): 1915-1934. http://dx.doi.org/10.1017/S0031182009991156. PMid:19835643.

Silva KR, Mendonça RRV, Silva KM, Nascimento LFM, Mendes-Sousa AF, Pinho FA, et al. Scoring clinical signs can help diagnose canine visceral leishmaniasis in a highly endemic area in Brazil. Mem Inst Oswaldo Cruz 2017; 112(1): 53-63. http://dx.doi. org/10.1590/0074-02760160305. PMid:28076469.

Solano-Gallego L, Miró G, Koutinas A, Cardoso L, Pennisi M, Ferrer L, et al. LeishVet guidelines for the practical management of canine leishmaniosis. Parasit Vectors 2011; 4: 86. http://dx.doi.org/10.1186/1756-3305-4-86. PMid:21599936.

Souza VMM, Julião FDS, Neves RCS, Oliveira LDC, Leal DC, Bisinotto TV, et al. Estudo epidemiológico de um surto de leishmaniose visceral numa área de manguezal. Gaz Méd Bahia 2006; 76(1): 14-24.

Trüeb I, Portela RD, Franke CR, Carneiro IO, Ribeiro G Jr, Soares RP, et al. Trypanosoma cruzi and Leishmania sp. infection in wildlife from urban rainforest fragments in northeast Brazil. J Wildl Dis 2018; 54(1): 76-84. http://dx.doi.org/10.7589/2017-01017. PMid:28977769. 